\title{
Najnowsza monografia o polskich synodach prowincjonalnych w średniowieczu: Pavel Otmar Krafl, Polské provinciální synody 13. - 15. století, Práce Historického ústavu AV ČR, Opera Jnstituti bistorici Pragae, ̌̌Rada / Series A Monograpbia, Svazek / Volumen 70, Historický Ústav, Praba 2016, ss. 176
}

\begin{abstract}
The Newest Monograph Concerning Polish Provincial Synods in the Middle Ages: Pavel Otmar Krafl, Polské provinciální synody 13. - 15. století, Práce Historickébo ústavu AV ČR, Opera Instituti historici Pragae, Rada / Series A Monographia, Svazek / Volumen 70, Historický Ústav, Praha 2016, ss. 176

The book being analyzed presents the current research on the synods of the Gniezno province of the Church in the Middle Ages. One of the notable merits of this monograph is its very rich footnotes, which give a broad view of the available literature on the topic. The author emphasizes the independence of the bishops' synods from those of the dukes. The review pays particular attention to e.g. the problem of quotations which were discredited as plagiarisms.
\end{abstract}

Keywords: synods, Middle Ages, Kingdom of Poland, canon law.

Słowa klucze: synody, średniowiecze, Królestwo Polskie, prawo kanoniczne.

Zgromadzenia biskupów polskiej prowincji kościelnej zwane synodami prowincjonalnymi odegrały wielką rolę $\mathrm{w}$ umocnieniu położenia prawnego Kościoła w średniowiecznej Polsce, zwłaszcza w okresie dzielnicowym. Przyczyniły się one wydatnie do głębokiej strukturalnej przebudowy społeczeństwa polskiego in capite et membris 
przez recepcję wzorców prawnych znanych wcześniej w zachodniemu chrześcijaństwu ${ }^{1}$ Synody prowincjonalne gnieźnieńskie stanowią przedmiot badań naukowych od dłuższego już czasu. Wybitne zasługi dla poznania ich organizacji i działalności, a także treści ustawodawstwa synodalnego, położyli w szczególności Władysław Abraham, Jan Fijałek, Stanisław Zachorowski, Bolesław Ulanowski, Ignacy Subera, Władysław Wójcik, Adam Vetulani. Grono to powiększają wydawcy średniowiecznych polskich statutów synodalnych, którymi są Antoni Zygmunt Helcel, Romuald Hube, Udalryk Heizman, Jakub Sawicki. Synody biskupów polskich w średniowieczu były fragmentem szerszego zjawiska rozwoju synodalności, jaki uwidocznił się w Kościele łacińskim po reformie gregoriańskiej. Synody, zwłaszcza te zwoływane i kierowane przez legatów papieskich, umacniały jego jedność i hierarchiczność. Jednym ze współczesnych badaczy dziejów synodów Kościoła w średniowiecznej Polsce jest czeski mediewista Pawel Otmar Krafl, pracownik naukowy Instytutu Historycznego Czeskiej Akademii Nauk w Brnie. Ogłosił on w przeszłości kilka prac z tego zakresu, jak np. Přehled provinciálnich synod Hnězdna z let 1206-1503, „Slovanské historické studie” 1999, nr 25, s. 5-34; czy Provinciální synody hnězdenske církevní provincie do začatku 16. století, „Prawo Kanoniczne” 2000, t. 43, s. 37-78. Godne uznania są też jego wydawnictwa czeskiego ustawodawstwa synodalnego [P. Krafl, Synody a statuta olomoucké diecéze obdobi středověku. Medieval synods and statutes of the diocese of Olomouc, PHU, rada B Editiones, sv.10, Praha 2014]. Był też głównym organizatorem sympozjum poświęconego średniowiecznemu prawu kanonicznemu i redaktorem obszernego wydania akt pt. Sacri canones servandi sunt. Ius canonicum et status ecclesiae saeculis XIII-XV, red. P. Krafl, PHÚ, řada C Miscellanea, sv.19, Praha 2008. Wykorzystując swoje wcześniejsze prace i posiadaną wiedzę, Pavel Krafl zdecydował się na przygotowanie i opublikowanie drukiem monografii poświęconej synodom prowincjonalnym odbywającym się w średniowiecznej Polsce. Książka ta ukazała się drukiem w 2016 r. pod wskazanym wyżej tytułem w ramach wydawnictw naukowych Instytutu Historii Czeskiej Akademii Nauk. Ze względu na znaczenie tego studium dla historii prawa kościelnego w średniowiecznej Polsce warto mu poświęcić naszą uwagę.

Praca składa się z trzech części. Pierwsza obejmuje krótki wstęp (s. 7-8) przedstawiający podjęte zamierzenie badawcze. Mam wątpliwości, dlaczego wśród nazwisk uczonych polskich zajmujących się w przeszłości tematyką synodalną zabrakło Ignacego Subery, którego opracowanie Synody prowincjonalne arcybiskupów gnieźnieńskich (Akademia Teologii Katolickiej, Warszawa 1971, ss. 185) zachowuje po dziś dzień wartość naukową, a wkład badawczy do poznania problematyki synodów prowincjonalnych w Polsce był znaczny. Notabene, publikacja ta figuruje w następującym z kolei spisie źródeł i literatury (s. 9-22). Samo zestawienie źródeł obejmuje wyłącznie wydawnictwa drukowane w liczbie 55 publikacji. Ujęto w nim łącznie starodruki oraz edycje źródłowe z XIX i XX w. Do tych pierwszych należą: Constitutiones synodorum Ecclesiae Gnesnensis Provincialium... Jana Wężyka (1761), Constitutiones synodorum metropolitanae ecclesiae Gnesnensis provincialium Stanisława Karnkowskiego (1579), Commune incliti Poloniae Regni privilegium... Jana Łaskiego (1506), Sacrorum

1 A. Vetulani, Przenikanie zasad powszechnego prawa kanonicznego i prawa rzymskiego do piastowskiej Polski [w:] idem, Z badań nad kultura prawnicza w Polsce piastowskiej, Wrocław 1976, s. 106 i n. 
conciliorum nova et amplissima collectio I.D. Mansiego (1779-1782), Statuta provinciae Gnesnensis antiqua et nova, revisa diligenter et emendata (1528). Osobiście za bardziej prawidłowe uważam wyodrębnienie starych druków i niełączenie ich z wydawnictwami źródłowymi. Wśród tych ostatnich wymienione zostały dyplomatariusze, odrębne wydania ustawodawstwa synodalnego, kronik, źródeł prawa i praktyki administracyjnej i sądowej. Następujący kolejno spis literatury obejmuje 165 pozycji. Figurują w nim książki i artykuły dotyczące średniowiecznego Kościoła w Polsce, odbywanych w średniowieczu synodów legackich i prowincjonalnych oraz ustawodawstwa synodalnego. Do literatury zaliczono także pozycje dawniejsze, jak: Compendium annalium ecclesiasticum... (Pragae 1726), S. Damalevicius, Series episcoporum Gnesnensium... (1649), Szymona Starowolskiego Epitome conciliorum... (Romae 1653). Wykaz literatury nie jest kompletny. Tytułem przykładu wskażę na pominięcie w tym wykazie ważnej pracy A. Vetulaniego Przenikanie zasad powszechnego prawa kanonicznego i prawa rzymskiego do piastowskiej Polski [w:] Z badań nad kultura prawnicza w Polsce piastowskiej, s. 95-128. Zamiast powoływania podręcznika akademickiego J. Bardacha, B. Leśnodorskiego, M. Pietrzaka, Historia ustroju i prawa polskiego, Warszawa 1997, wyd. 4, wskazane byłoby wykorzystanie J. Bardacha, Historia państwa i prawa Polski, t. I: Do połowy XV, wyd. 2, Warszawa 1964, które stanowi podstawowe opracowanie tego autora. Pro domo sua, upomniałbym się o umieszczenie w bibliografii także syntezy W. Uruszczaka, Historia państwa i prawa polskiego tom I (966-1795), wyd. 3, Lex a Wolters Kluwer business, Warszawa 2015. Część wstępną kończy zestawienie stosowanych w pracy skrótów.

Część druga opracowania składa się z ośmiu rozdziałów. Rozdział I zawiera sumaryczny przegląd źródeł i literatury. Rozpoczyna go krótki podrozdział 1 wymieniający autorów prac o charakterze ogólnym, syntetycznym i przeglądowym. Treść drugiego podrozdziału wypełnia prezentacja źródeł zarówno historiograficznych, jak prawnych. Do tych ostatnich należą edycje źródłowe statutów synodalnych. Zasadniczo prezentację tę autor ograniczył do wskazania nazwisk autorów najważniejszych wydawnictw. Nie pokusił się o ocenę ich wartości poznawczej. Z kolei w trzecim podrozdziale przedstawiona została literatura naukowa poświęcona synodom legackim i uchwalonym przez nie statutom. Prezentacja ma charakter poszerzonej bibliografii bez bliższego omówienia treści prezentowanych publikacji. Nieco ciekawiej przedstawia się podrozdział czwarty zatytułowany „Literatura o provinciálních synodach a statutech hnězdenských arcibiskupư". Omówienia poszczególnych prac są niekiedy - choć nie w każdym przypadku - obszerniejsze. Zwraca uwagę nazwisko Stanisława Tymosza, wymieniane obok nazwisk wielu innych czołowych polskich badaczy. W mojej ocenie wkład Stanisława Tymosza do badań nad synodami i ustawodawstwem synodalnym w średniowiecznej Polsce kwalifikuje się jako rodzaj naukowego przetwórstwa polegającego na nierzetelnym parafrazowaniu, noszącego wyraźne znamiona zapożyczeń z prac innych autorów bez wyraźnego własnego wysiłku badawczego. Dlatego byłoby lepiej, gdyby prace tego rodzaju znikły z naukowego obiegu, choć to najprawdopodobniej nigdy nie nastąpi.

W krótkim rozdziale 2 pt. „Institut legátské a provinciální synody” zostały omówione synody legackie i prowincjonalne w świetle obowiązującego w średniowieczu prawa kanonicznego. Zwoływanie synodów należało do obowiązków legata papieskiego, a także arcybiskupa i biskupów. Szczegółowe regulacje w tym zakresie zawierały Dekretały 
Grzegorza IX, Liber Sextus czy niektóre statuty legackie z 1279 r. i prowincjonalne (1406), recypowane z kolei do zbioru Mikołaja Trąby z 1420 r. Rozdział 3 zatytułowany „Sjezdy biskupou a knizetci kolokwia” został poświęcony doniosłemu zagadnieniu relacji między synodami a wiecami książęcymi (kolokwia). Te pierwsze, jako instytucje kościelne, gromadziły biskupów. Na tych drugich poza dostojnikami świeckimi, obecni byli także biskupi. W nauce zauważono, że podczas takich wieców odbywały się także zjazdy biskupów.

W rozdziale 4 zebrano informacje o statutach legackich dotyczących Polski. Były to statuty wrocławskie z 1248, 1253 i 1267 r., a nadto wydane w Budzie (1279) i Preszburgu (1302 i 1309). Wątpliwe jest, jak zauważa autor, aby Polski dotyczył statut z Wurzburga (1287), o czym informował osiemnastowieczny wydawca Joannes Dominicus Mansi. Bliższą prezentację treści statutów wydanych na synodach prowinicjalnych zamieszczono w rozdziale 5 pt. Provinciálni synody hnězdenských arcibiskupě do počátku 16. století. Przedstawiono w nim najpierw synody do 1326 r. (podrozdz. 5.1), a następnie synody od poł. XIV do poł. XV w., na których doszło do kodyfikacji statutów synodalnych w postaci Synodyku Jarosława (1357) i zbiorze arcybiskupa Mikołaja Trąby (1420). W trzecim podrozdziale opisano synody z drugiej poł. XV w. i początku XVI w., zwoływano przeważnie dla podjęcia uchwał w sprawie kontrybucji od duchowieństwa (subsidium charitativum).

W rozdziale 6 pt. „Charakteristiki provinciálních synod” przypomniano, że synody zwoływane w XIII i na początku XIV w. zajmowały się walką o pozycję Kościoła, w szczególności o jego niezależność od władzy świeckiej w imię libertatis ecclesiae. Wtedy też uchwalane wówczas statuty wprowadzały w życie zasady powszechnego prawa kanonicznego. Z kolei w drugiej poł. XIV i pierwszej poł. XV w. obrady synodów zajmowała sprawa kodyfikacji wcześniej wydanych statutów, co zaowocowało takimi zbiorami, jak Synodyk Jarosława i zbiór Mikołaja Trąby. W drugiej poł. XV w. obrady synodalne zdominowały sprawy ponoszonych przez kler na rzecz państwa ciężarów finansowych. W rozdziale tym poruszono także inne kwestie, jak przyczyny i inicjatywa zwołania, termin zwołania i czas trwania, uczestnicy obrad, procedura zwołania. Rozdział kończą uwagi o tematyce obrad, podkreślając fakt, że synody zajmowały się często sprawami aktualnymi dla Kościoła i państwa. Często były to spory między biskupami. W rozdziale 7 zamieszczono sumaryczny przegląd omawianych statutów, począwszy od najstarszych, wydanych na synodach zwołanych przez arcybiskupa Henryka Kietlicza, a skończywszy na kodyfikacji Mikołaja Trąby. Za pożyteczne należy uznać w szczególności uwagi w przedmiocie statutów zachowanych we fragmentach, takich jak statut Crescente quottidie czy De anno gratie. W krótkim podsumowaniu stanowiącym rozdział 8 (s. 90) zawarto istotną konkluzję: ,synodálni ,život” a tvorba právnich norem partikulárního prava církevního byly velmi pestré, různorodé a bohaté" (s. 90). Zasadniczym celem tego ustawodawstwa była adaptacja powszechnego prawa kanonicznego potrzeb polskiego Kościoła.

Bardzo wartościowa pod względem poznawczym jest część trzecia prezentowanej monografii zawierająca trzy katalogi. Pierwszy to katalog statutów legackich (s. 91103). Objęto nim osiem tego rodzaju aktów prawnych. W katalogu podano informacje o dacie promulgacji danego statutu, jego publikacji drukiem oraz zamieszczono spis rubryk artykułów i wykaz najważniejszej literatury. Jako drugi występuje katalog syno- 
dów prowincjonalnych gnieźnieńskich (s. 104-138). Dane w nim zamieszczone to data obrad, imię arcybiskupa, informacje źródłowe, a nadto podano wykaz imienny uczestników danego synodu oraz literatury naukowej. W odniesieniu do tego drugiego katalogu nasuwają się jednak pewne uwagi. Katalog synodów prowincjonalnych archidiecezji gnieźnieńskiej ogłosił w 1971 r. Ignacy Subera w powołanej wyżej publikacji. Katalog ten jest przywoływany w ramach wykazanej literatury, ale w tekście Pawla Krafla nie ma próby jakiejkolwiek konfrontacji. Tymczasem między oboma tymi katalogami zachodzą różnice. Katalog Krafla jest obszerniejszy, gdyż wykazuje za okres od pontyfikatu Henryka Kielicza do pontyfikatu Andrzeja Boryszewskiego 63 synody. W katalogu Subery za okres 1210-1485 wymieniono ich zaledwie 33, nie licząc synodów zwołanych w końcu XV w. przez kardynała Fryderyka Jagiellończyka (1493-1503) i arcybiskupa Boryszewskiego (1503-1510). Zostały one w katalogu w zasadzie pominięte, gdyż zawarto o nich tylko krótką wzmianką w zakończeniu opisu synodu z 1485 r. (por. I. Subera, Synody..., s. 97). Treść katalogu sporządzonego przez Pawla Krafla jest bogatsza. Nasuwa się jednak pytanie: Dlaczego autor wśród synodów arcybiskupa Wojciecha Jastrzębca nie wymienił synodu łęczyckiego z 1423 r.? (P. Krafl, s. 70, 123; por. I. Subera, Synody..., s. 89). Poza tym opisy poszczególnych synodów zamieszczone w katalogu Pawla Krafla zdają się niekiedy uboższe, zwłaszcza w przedmiocie podejmowanych na tych synodach uchwał. Choć więc katalog synodów prowincjonalnych gnieźnieńskich odbytych w okresie od XIII do XV w. autorstwa prof. Krafla jest pełniejszy, to jednak czytelnik będzie i tak musiał sięgać do katalogu Ignacego Subery. Wreszcie trzeci katalog opracowany przez P. Krafla obejmuje wykaz statutów prowincjalnych (s. 139-150). Rozpoczyna go statut synodu w Kamieniu, a kończy statut synodu łęczyckiego z 1503 r. Informacje zawarte w katalogu obejmują dane o wydaniach drukowanych danego statutu oraz wykaz poszczególnych artykułów przedstawianych w postaci krótkiego jednozdaniowego streszczenia. Na końcu opracowania zamieszczony został indeks osobowo-miejscowy (s. 151-170) oraz streszczenie całości w języku polskim.

Omawiane tutaj opracowanie oceniam wysoko. Przedstawia ono aktualny stan badań nad synodami gnieźnieńskiej prowincji kościelnej w wiekach średnich. Zaletą pracy jest bogaty aparat przypisów, dający czytelnikowi pełny przegląd źródeł i literatury przedmiotu. Autor podkreśla niezależność synodów biskupich od władzy książąt dzielnicowych. Warto tutaj zaznaczyć, że w XIII w. synody prowincjonalne, gromadzące biskupów całej prowincji gnieźnieńskiej, były przejawem jedności Kościoła polskiego i tym samym ważnym czynnikiem sprzyjającym tendencjom zjednoczeniowym. 